\title{
MANAGEMENT OF PSORIASIS: A COMPARATIVE CLINICAL STUDY OF STANDARD AYURVEDA \& ALLOPATHIC PROTOCOLS
}

\author{
Dr. Sameer Shinde ${ }^{\circledR}$, Dr.Puneet Bhargava ${ }^{2}$, Dr. Daya Shanker Mishra ${ }^{3}$ \\ P.G. Scholar, P.G. Department. Of Kayachikitsa, National Institute of Ayurveda Jaipur. \\ ${ }^{2}$ Associate Professor SMS Medical College, Jaipur. \\ ${ }^{3}$ Associate Professor P.G. Department of Kayachikitsa, National Institute of Ayurveda Jaipur.
}

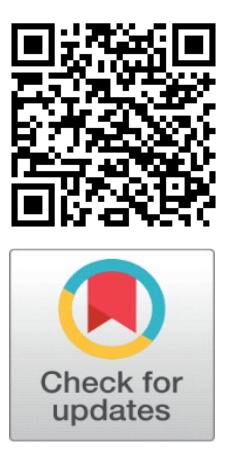

Received 3 July 2021

Accepted 19 August 2021

Published 31 August 2021

\section{CorrespondingAuthor}

Dr. Sameer Shinde,

sameershubha85@gmail.com

DOI

10.29121/granthaalayah.v9.i8.2021. 4190

Funding: This research received no specific grant from any funding agency in the public, commercial, or not-for-profit sectors.

Copyright: (C) 2021 The Author(s). This is an open access article distributed under the terms of the Creative Commons Attribution License, which permits unrestricted use, distribution, and reproduction in any medium, provided the original author and source are credited.

\section{ABSTRACT}

Psoriasis is a common, chronic and non- infectious skin disease characterized by welldefined slightly raised, dry erythamatous macules with silvery scales Modern medicine offers treatment with PUVA, Corticosteroids \& Anti mitotic Drugs but therapy gives serious side effects like Bone Marrow depletion, Liver \& kidney Failure. While treating Kustha, Ayurvedic Classics especially focused on Panchakarma Treatment. So Vaman, Virechana \& Laghu-Manjisthadi Ghan was selected for trial. Total 30 well diagnosed patients were selected \& divided in two groups. One group receiving Ayurvedic Treatment \& other Allopathic Regimen (Tb. Methotraxate7.5 mg/week) for 2 months \& comparative study was done. Assessment was done on improvement in clinical symptoms as well as on Laboratory parameters.

Keywords: PUVA, Methotrexate, Psoriasis

\section{INTRODUCTION}

Psoriasis is a papulosquamatous disorder of skin characterized by sharply defined erythamatous lesions. It is notoriously chronic \& is well known for its course of remission \& exacerbation. In India approx 80 lakhs (0.8\%) Population is affected by this dreadful disease. The exact cause is still unknown. The intensity of disease is such high that to increase awareness among people, patients \& doctors 29 October is officially declared as "World Psoriasis Day". Modern medicine offers treatment with PUVA, Corticosteroids \& Antimitotic Drugs. But therapy gives serious side effects like Bone Marrow depletion, Liver \& kidney Failure.

Classical Ayurveda treats this disease as a one of a type of Kustha. Besides all treatments while treating the Kustha all Acharyas specially focused on Panchakarma (Shodhana Therapy) to control \& to prevent the remission. As Kustha is also described as one of a Raktapradoshaj vyadhi so Laghumanjisthadi Ghan having Raktashodhak, Raktaprasadak, kushthaghna kandughna properties was selected for trial \& a clinical comparative study was done.

\section{Need of Study}

A lot of research work has been done on treatment of Psoriasis in both modern \& Ayurveda Sciences \& lot of is still going on. Each science has its own claims over the management \& success rate. But still a promising cure for Psoriasis is not found. According to the survey of the US National Psoriasis Foundation on 40,350 
patients shows that $78 \%$ of severe psoriatic Patients were still frustrated by the lack of efficacy of treatment. Archives of Dermatology (2001) So now a day it became essential to find out a safe, economic, effective treatment for psoriasis.

\section{AIMS \& OBJECTIVES}

Present study was undertaken with following aims \& objectives

- Conceptual \& clinical study on Psoriasis according to Ayurveda as well as Modern science on various scientific parameters.

- Clinical evaluation of role of Vaman, Virechana \& Laghu-Manjisthadi Ghana in Management of Psoriasis.

- A comparative clinical study of trial drug along with standard allopathic regimen.

\section{MATERIALS \& METHODS}

\section{Selection of patients}

The study was conducted on 30 clinically diagnosed \& confirmed cases of Psoriasis from OPD \& IPD section of National institute of Ayurveda Jaipur \& S.M.S. Medical College \& hospital Jaipur.

\section{Criteria of diagnosis}

The main criteria of diagnosis of patients were based on the cardinal and associated signs and symptoms of the disease based on the Ayurvedic and modern texts. These have been depicted in detail in the criteria of inclusion.

\section{Inclusion criteria}

1) Patients between the age group of 15 to 60 yrs in either sex presenting clinical symptoms of disease.

2) Patients willing to sign the consent form.

\section{Exclusion criteria}

1) Patients with age below $15 \&$ above 60 yrs.

2) Pregnant women's \& lactating mothers.

3) Patients suffering from serious systemic disorders like Diabetes Mellitus, Cardiac \& Renal Disorders, Malignant disease etc.

4) Patients Contraindicated for Vaman \& Virechana as per classical Ayurvedic Texts.

\section{Method of study (protocol of Study)}

\section{Consent}

Written informed consent was taken on prescribed Performa before the inclusion of patient in trial. They are briefed about merits and demerits of research plan before taking consent.

\section{Therapeutic study}

- Selection of the trial drug: Drug selected for current clinical trial was Laghu Manjisthadi Ghana. Tripathi (2008)

- Dose: 2 gm / day (2 Capsules BD).

- Duration of Trial: 2 months. 
- Randomization of patients: All the patients fulfilling the criteria of diagnosis and inclusion were randomly divided into two groups named as Trial Group A \& Trial Group B consisting 15 patients each.

1) Group A: 15 registered patient of Psoriasis was administered LaghuManjisthadi Ghan capsule 2 BD after Vaman \& Virechana.

2) Group B: 15 registered patient of Psoriasis was administered Standard allopathic drug named Neotrexate (Methotrexate) 7.5 mg / week $(2.5 \mathrm{mg}$ for 3 times at 12 hourly 8pm- 8 am-8pm/week) under observation of concern expert supervisor.

For local application patients in Group A were advised to apply Panchatikta ghrita \& in Group B routine allopathic topical application Protar lotion (Coal Tar 5\%) was advised as per instruction of supervisor

\section{Method of preparation}

- The ingredients of the trial drug i.e. Manjistha, Guduchi, Haritaki, Amalaki, Vibhitaki Vacaha, Daruharidra, Nimb \& Kutaki were taken into equal amount and decoction was made per instructions in Sharangdhar Samhita. Then the decoction was again heated on water bath \& active extract was collected then Capsules of $500 \mathrm{mg}$ each was made in pharmacy of NIA Jaipur.

\section{Vaman Karma}

- Procedure of Vaman was carried out as follows, Pachana with Panchkol Churna 3 gm BD for 3 days, Snehpan was done with Panchtikta grhit till samyak sneh lakshana was observed, then Sarvang Snehan Swedan was done. Vaman was induced by Madanphaladi yoga (Madanphal Pippali + Vacha+ Saindhav+ Honey) then Dhoompan \& Sansarjankram was carried out.

\section{Virechana Karma}

- Pachana with Panchkol churna 3 gm BD for 3 days after that Snehpan with Panchtikta Grhit till samyak Sneha lakshana were observed then Sarvang snehan Sweden for 2 days \& Virechana with Abhayadi Modak Tripathi (2008) was done. Proper Sansarjankram was advised.

\section{Criteria for Assessment}

Assessment of clinical improvement was done according to severity of sign \& symptoms. To assess the efficacy of treatment following criteria was adopted.

\section{Subjective Criteria}

\section{PASI SCORE (Psoriasis area \& Severity Index)}

PASI Score was considered as both subjective \& objective criteria as it covers both subjective as Erythema, scaling \& indurations and objective parameters as coverage area.

\section{Kandu (Itching index)}

Symptom rating scale was as follows

0: No Itching

1: Mild Itching comes occasionally, duration $2 / 3 \mathrm{~min}$,

2: Moderate itching occurs frequently, lasts for longer time, scratching is essential.

3: Severe Itching, occurs frequently, lasts More than 20-30 min, bleeding on

Scratching. 


\section{Daha (Burning index)}

Symptom rating scale was as follows

0 : No burning.

1: Mild burning comes occasionally, duration 2-3 min.

2: Frequent burning sensation more than 3 times last for $10 \mathrm{~min}$.

3: Severe burning sensation more than 5 times, lasting more than $15 \mathrm{~min}$, disturbs daily routine.

\section{Laboratory Parameters}

Routine blood Investigation (Hb\%, TLC, ESR).

Liver function test (SGOT, SGPT)

\section{Overall Effect of Therapy}

Each patient was assessed on the basis of signs \& Symptoms of the disease on the basis of grading pattern as well as percentage relief, patients were classified as follows.

\begin{tabular}{ll}
\hline Complete improvement & $100 \%$ relief \\
\hline Marked improvement & More than $75 \%$ relief \\
\hline Moderate improvement & 50 to $75 \%$ relief \\
\hline Mild Improvement & 25 to $50 \%$ relief \\
\hline No Improvement & Below $25 \%$ or no relief \\
\hline
\end{tabular}

\section{OBSERVATION \& RESULTS}

All selected patients successfully completed the trial. Obtained observations were analyzed statistically with the help of INSTAT GRAPHPAD $3 \&$ the obtained results are as follows:

(Wilcox son matched pair single ranked test was applied.)

\begin{tabular}{|c|c|c|c|c|c|c|c|c|c|}
\hline \multirow[t]{2}{*}{ Variable } & \multirow[t]{2}{*}{ Group } & \multicolumn{2}{|c|}{ Mean } & \multirow[t]{2}{*}{ MeanDiff. } & \multirow[t]{2}{*}{$\%$ Relief } & \multirow[t]{2}{*}{ SD \pm} & \multirow[t]{2}{*}{ SE \pm} & \multirow[t]{2}{*}{$\mathbf{p}$} & \multirow[t]{2}{*}{$S$} \\
\hline & & BT & AT & & & & & & \\
\hline \multirow[t]{2}{*}{ PASI Score } & Gr. A & 21.8 & 6.99 & 14.28 & 67.13 & 8.30 & 2.14 & 0.0001 & HS \\
\hline & Gr. B & 19.32 & 5.97 & 13.35 & 69.09 & 7.29 & 188 & 0.0001 & HS \\
\hline \multirow{2}{*}{$\begin{array}{c}\text { Kandu } \\
\text { (Itching Index }\end{array}$} & Gr. A & 2.66 & 1 & 1.66 & 62.5 & 0.72 & 0.98 & 0.0001 & HS \\
\hline & Gr. B & 2.46 & 1.13 & 1.13 & 54.06 & 0.72 & 0.16 & 0.0002 & HS \\
\hline
\end{tabular}


Daha

(Burning Index)

$\begin{array}{lllllllll}\text { Gr. B } & 1.13 & 0.53 & 0.6 & 52.9 & 0.63 & 0.16 & 0.0078 & \text { S }\end{array}$

(HS: highly Significant

\section{$\begin{array}{lllll}57.14 & 0.41 & 0.10 & 0.0005 & \text { HS }\end{array}$}

\section{Effect on Total PASI Score}

In Group A the mean PASI Score of before treatment was 21.82. It lowered down to 6.99 with $\mathrm{SD} \pm 8.30$ giving a relief of $67.13 \%$ which was statistically highly significant.

In Group B the mean PASI Score of before treatment was 19.32. It lowered down to 5.97 with $\mathrm{SD} \pm 7.29$ giving a relief of $69.09 \%$ which was statistically highly significant.

\section{Effect of Drug on Kandu (Itching Index)}

In Group A Mean Itching index before treatment was 2.66 which was reduced to 1 showing $62.5 \%$ relief which is statistically highly significant.

In Group B mean Itching index before treatment was 2.46 which was reduced to 1.33 showing $54.05 \%$ relief which is statistically highly significant.

Effect of Drug on Daha (Burning Index)

In Group A mean burning index before treatment was 1.4 which was reduced to 0.6 showing $57.14 \%$ relief which is statistically highly Significant.

In Group B mean burning index before treatment was 1.13 which was reduced to 0.53 showing $52.9 \%$ relief which is statistically.

Table 2: Calculation Details of Wilcox son matched pair test are as follows

\begin{tabular}{|cccccc}
\hline Variable & Group & W & T+ & T- & No. of Pairs \\
\hline PASI Score & A & 118.00 & 119.00 & -1.000 & 15 \\
\hline & B & 118.00 & 119.00 & -1.000 & 15 \\
\hline Itching Index & A & 105.00 & 105.00 & 0.000 & 14 \\
\hline Burning Index & B & 91.000 & 91.000 & 0.000 & 13 \\
\hline & A & 78.000 & 78.000 & 0.000 & 12 \\
\hline
\end{tabular}

(W= Sum of all Signed ranks, $\mathrm{T}+=$ sum of Positive ranks, $\mathrm{T}-=$ Sum of negative ranks) 


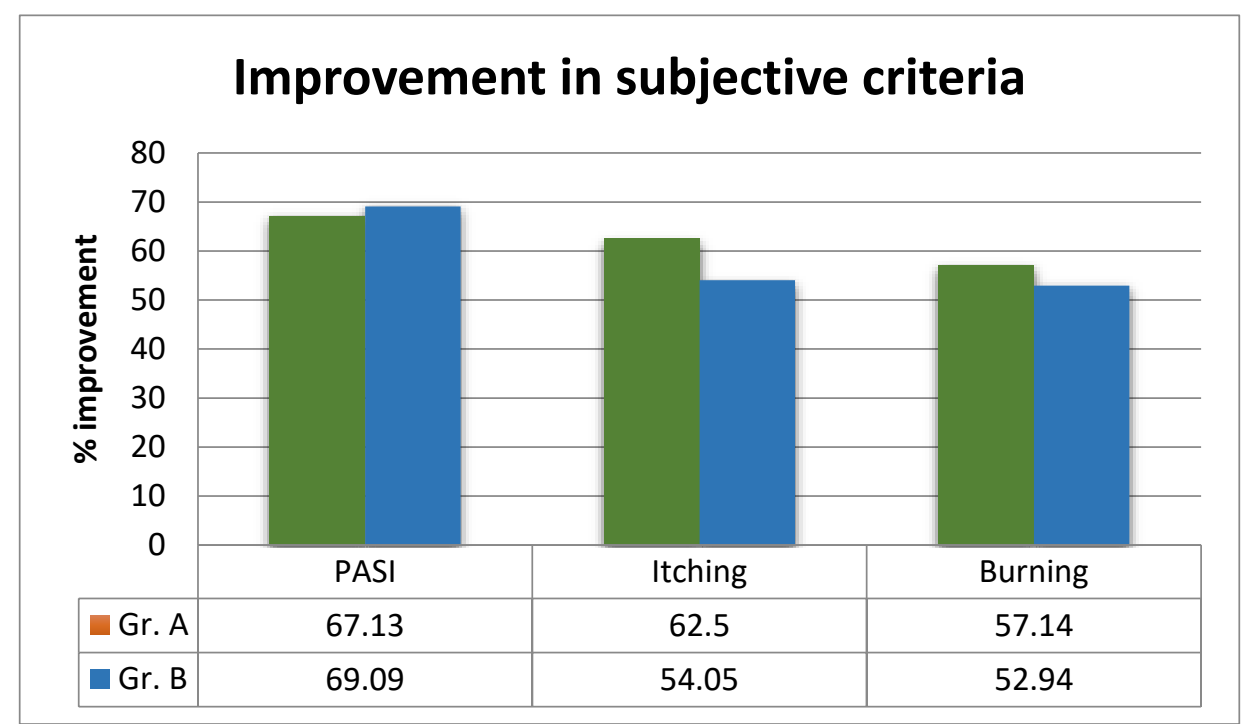

Graph no 1: Showing Improvement in subjective criteria.

\section{Intergroup Comparison}

To access the efficacy of two therapies intergroup comparison was done. As the variables are nonparametric, we used Mann-Whitney Test for stastically analysis. The results are as follows

\begin{tabular}{|ccccccccc|}
\hline \multicolumn{6}{|c|}{ Table 3: showing Intergroup Comparison of Group A \& Group B } \\
\hline Variable & Groups & Mean & diff. & SD \pm & SE \pm & P & S \\
\hline PASI Score & A & 14.28 & 8.30 & 2.14 & 0.7400 & NS \\
\hline Itching Index & A & 13.35 & 7.29 & 1.88 & & \\
\hline & B & 1.66 & 0.732 & 0.1869 & 0.2224 & NS \\
\hline Burning Index & A & 0.8 & 0.141 & 0.1059 & 0.2473 & NS \\
\hline & B & 0.6 & 0.632 & 0.1633 & & \\
\hline
\end{tabular}

Intergroup comparison shows that for all variables $\mathrm{p}$ value is statistically nonsignificant which clearly indicates that there is no statistically significant difference in the efficacy of the both drugs.

\begin{tabular}{|c|ccccc|}
\hline \multicolumn{4}{|c|}{ Table 4: Showing Calculations } & Details of intergroup comparison: \\
\hline Variable & $\mathbf{U}$ & U' & $\begin{array}{c}\text { Sum of ranks in } \\
\text { Gr. A }\end{array}$ & $\begin{array}{c}\text { Sum of ranks in } \\
\text { Gr. B }\end{array}$ \\
\hline PASI Score. & 104.00 & 121.00 & 241.00 & 224.00 \\
\hline
\end{tabular}




\begin{tabular}{|lrrrr|}
\hline Itching. & 85.500 & 139.50 & 259.50 & 205.50 \\
\hline Burning. & 88.500 & 136.50 & 256.50 & 208.50 \\
\hline
\end{tabular}

(U= Manwhitney's U statistics)

\section{Effect of Drug on Laboratory Parameters}

\section{- Hematological Investigations}

Patients were advised to go for lab investigation before $\&$ after Treatment. Data collected was analyzed \& students Paired ' $\mathbf{t}$ ' Test was applied. The results found are as follows...

\begin{tabular}{|c|c|c|c|c|c|c|c|c|c|c|}
\hline Variables & Group & AT & BT & Diff & $\%$ Imp & $\mathrm{SD} \pm$ & SE \pm & $\mathbf{t}$ & $\mathbf{p}$ & $\mathbf{S}$ \\
\hline \multirow[t]{2}{*}{ Hb\% } & A & 14.4 & 15.03 & 0.56 & 3.86 & 0.52 & 0.13 & 4.11 & $<0.01$ & S \\
\hline & B & 14.02 & 14.14 & 0.12 & 0.9 & 0.46 & 0.12 & 1.05 & $<0.1$ & NS \\
\hline \multirow[t]{2}{*}{ TLC } & A & 6786.6 & 6766.6 & 20 & 0.29 & 174.2 & 44.93 & 0.44 & $<0.1$ & NS \\
\hline & B & 6153 & 6180 & 26.66 & 0.43 & 174.9 & 44.95 & 0.59 & $<0.1$ & NS \\
\hline \multirow[t]{2}{*}{ ESR } & A & 34.73 & 20.4 & 14.33 & 41.26 & 13.35 & 3.44 & 4.15 & $<0.001$ & HS \\
\hline & B & 29.33 & 18.93 & 10.4 & 35.4 & 9.50 & 2.45 & 4.23 & $<0.001$ & HS \\
\hline
\end{tabular}

\section{- In Group A}

HB\%: Mean $\mathrm{Hb} \%$ before treatment was increased from $14.4 \mathrm{gm} \%$ to 15.03 having $3.86 \%$ improvement which is statistically significant.

TLC: Results obtained in TLC were not significant.

ESR: Mean ESR before treatment was reduced from 34.73 to $20.4 \mathrm{~mm} / \mathrm{hr}$ showing $41.26 \%$ improvement which is stastically highly significant.

\section{- In Group B}

HB\%: Mean $\mathrm{Hb} \%$ before treatment was increased from $14.02 \mathrm{gm} \%$ to 14.14 having $0.9 \% \%$ improvement which is statistically non-significant.

TLC: Results obtained in TLC were not significant.

ESR: Mean ESR before treatment was reduced from 29.33 to $18.93 \mathrm{~mm} / \mathrm{hr}$ showing $35.4 \%$ improvement which is stastically highly significant. 


\section{Changes in Hematological Parameters}

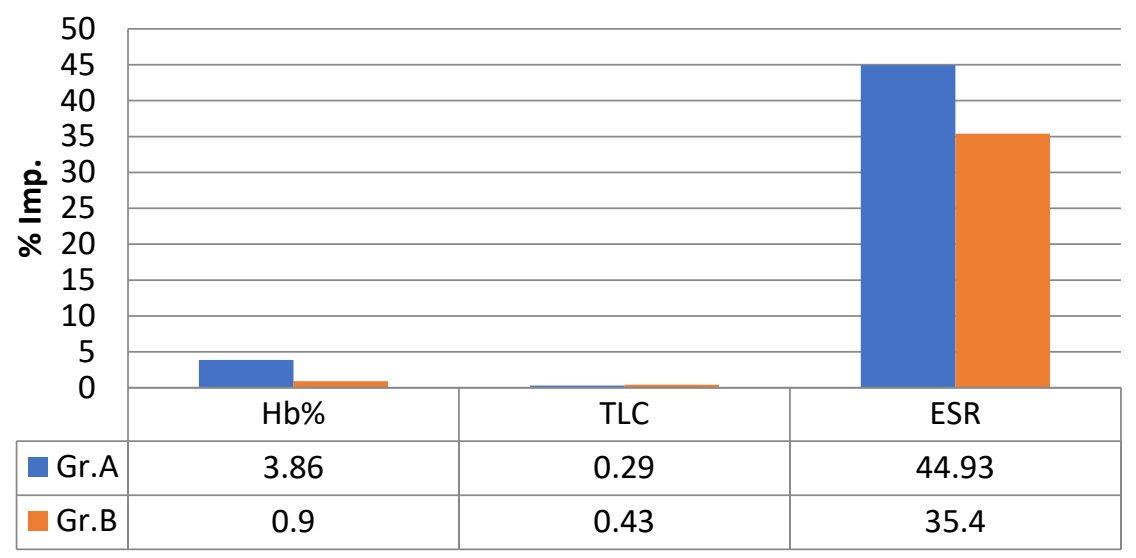

Graph 2: Showing changes in Hematological parameters.

\section{Effect on Liver Function Test:}

Changes in Liver function tests before \& after treatment are as follows...

Table 6: Showing Effect of Drug on LFT.

$\begin{array}{cccccccccccc}\text { Variable } & \text { Group } & \text { AT } & \text { BT } & \text { Diff } & \text { \% Imp } & \text { SD } \pm & \text { SE } \pm & \text { t } & \text { p } & \text { S } \\ & \text { A } & 26 & 28.06 & 2.06 & 9.09 & 5.57 & 1.44 & 1.80 & <0.05 & \text { NS } \\ \text { SGOT } & \text { B } & 26.13 & 36.53 & 10.4 & 39.79 & 9.68 & 2.50 & 4.14 & <0.01 & \text { S } \\ & \text { A } & 26.06 & 28.53 & 2.46 & 8.64 & 4.35 & 1.12 & 2.19 & <0.05 & \text { NS } \\ & \text { BGPT } & \text { B } & 29 & 38.8 & 9.8 & 33.79 & 10.5 & 2.59 & 3.77 & <0.01 & \text { S }\end{array}$

Changes occurred in SGOT \& SGPT were not significant in Group A In Group B

- SGOT: Level of SGOT was increase from 26.13 to 36.53 , showing $39.79 \%$ increase which is statistically significant.

- SGPT: Level of SGPT was increase from 29 to 38.8, showing $33.79 \%$ increase which is statistically significant. 


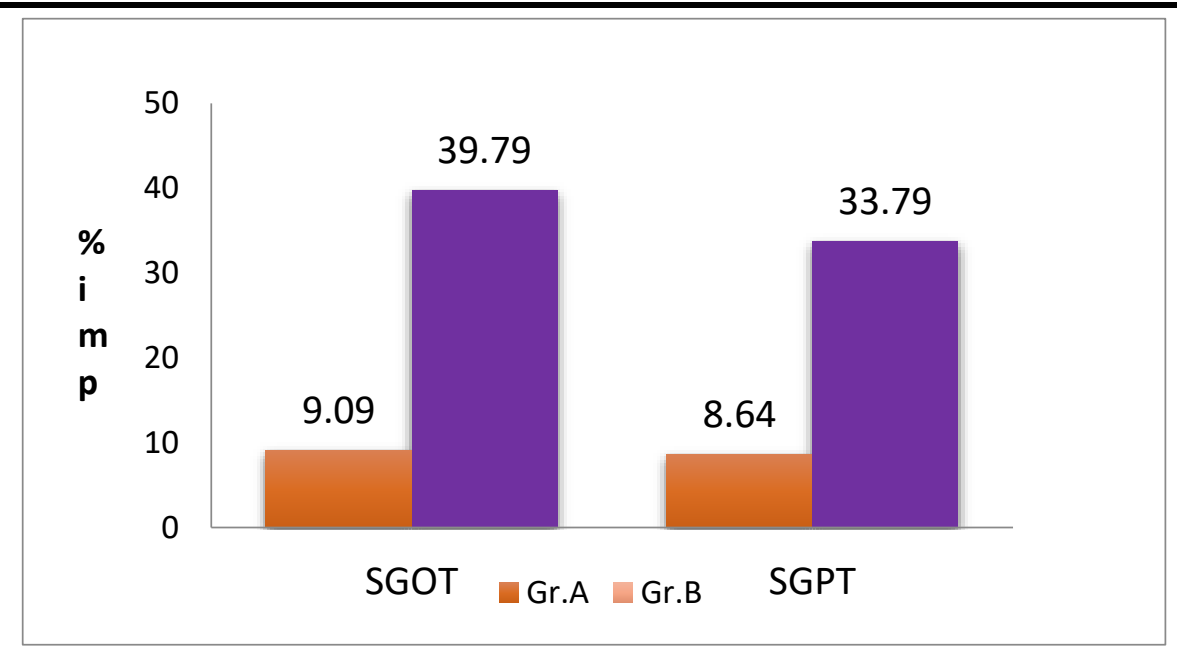

Graph 3: showing changes in LFT.

\section{Overall effect of Therapy}

In Group A: Complete improvement was observed in $20 \%$ patients; marked improvement was observed in $66.66 \%$ patients, moderate improvement was observed in $13.33 \%$ patients.

In Group B: Complete improvement was observed in 20\% patients; marked improvement was observed in $40 \%$ patients, moderate improvement was observed in $33.33 \%$ patients \& $6.66 \%$ Shows Mild improvement.

\section{Follow up Study}

Follow up study was done at $\mathbf{3 0}$ days $\boldsymbol{\&}$ 60days after successful completion of trial it shows that in group A out of 15 patients at the end of 2 months only 4 patients (26\%) show signs of remission on other hand in group B, 7 out of 15 patients (46.66\%) shows signs of remission.

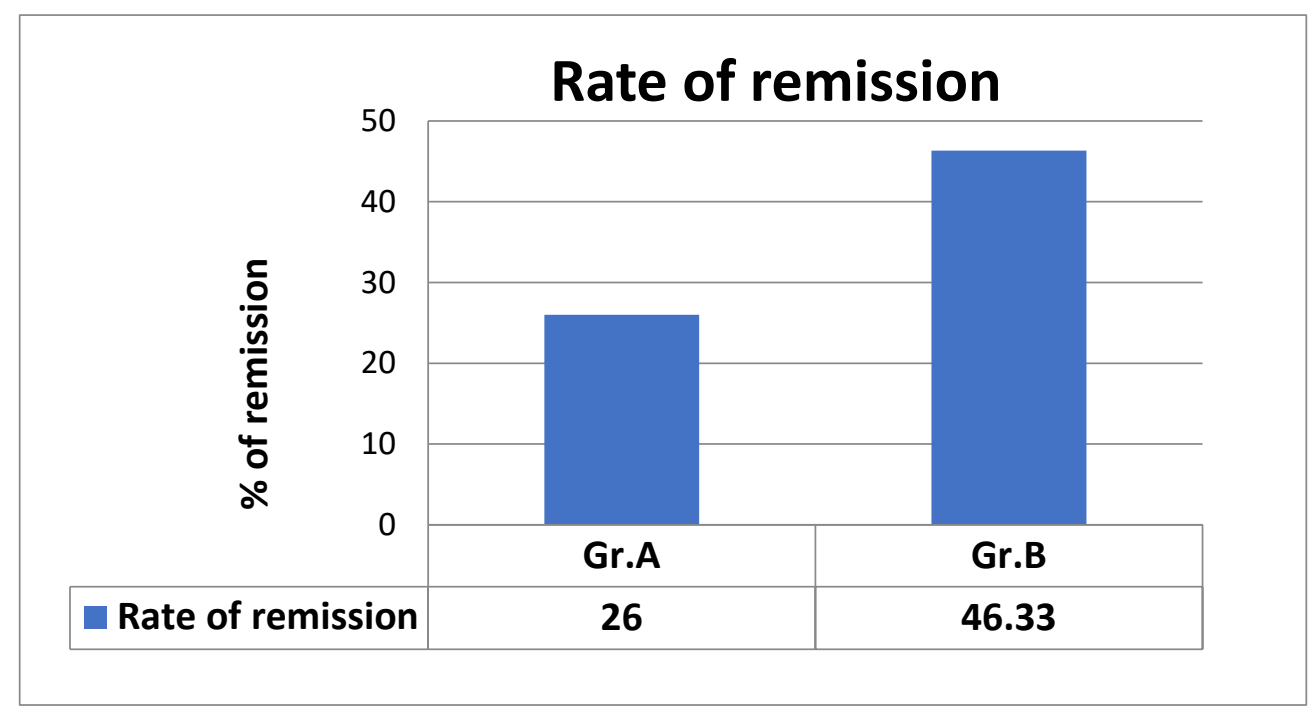

Graph 4: Showing Rate of remission in both groups. 


\section{DISCUSSION}

\section{Probable Mode of Action}

Laghu Manjisthadi Ghana

1) Main content of Laghu-Manjisthadi Ghana is Manjistha which has Raktashodhana \& Raktaprasadan Kusthaghna, Vishaghna, Varnya, property. Chunekar (2009) According to Ayurveda Yakrut \& Pleeha (Liver \& Spleen) are site of formation of Rakta dhatu. Shatri (2003) Kutaki, Daruharidra, Amruta are having potent Hepatoprotective action. These drugs act on the formation site of the Rakta dhatu \& break the basic pathogenesis of Kustha.

2) Recent research studies shows that Manjistha has potent inhibitory action on HaCa T cell Proliferation Wai-Pui et al. (2006) which plays key role in establishment of Psoriasis. It also has potent role in inhibiting Keratinocyte's proliferation Lin et al. (2010). This helps in reducing the rapid shading of epithelium in psoriasis.

3) Mollugin one of active principle of Manjistha showed inhibition of passive cutaneous anaphylaxis (PCA) and protection of mast cell degranulation in rats. Gupta et al. (1999) This reveals it has potent Anti-Itching \& Anti-Allergic Property.

4) Guduchi, Amalaki, Haritaki, Vibhitaki, Manjistha has potent Antiinflammatory, Analgesic, Antibacterial, Immunomodulatory, Antioxidant property Database on medicinal plants used in Ayurveda (2000). It plays key role in reducing inflammation \& early prematuration of cells.

5) Stress is one of the major trigger factors for disease; Vacaha having potent Medhya property helps in reducing stress Database of medicinal plants used in ayurvead (2000).

6) Drugs like Amruta, Amalaki, Haritaki; Vibhitaki has potent Rasayan property which helps in preventing the multiple relapses of the disease by strengthening body's own immune system. Shatry (2006)

7) According to Ayurveda treatment procedure kosthashodhan is the basic step in the management of Kustha. Triphala is the main ingredient of LaghuManjisthadi Ghana which is the one of the best medicines having property of Kosthashodhana.

8) Panch Tikta Ghrita contains Vasa, Nimb, Patol, Guduchi \& Kantakari. All these drugs have Tikta rasa, Kandughna \& kusthagna property Chunekar (2009).

9) According to dermal drug delivery system of modern science skin shows the better absorption of lipid \& lipid soluble substances than water soluble molecules Katare et al. (2010). So according to this theory Panchatikta ghrita shows better penetration in skin than other snehas with carrying properties of drugs added to it.

10) The patches of Psoriasis are dry \& Scaly. The Panchatikta ghrita provides proper moisture to it resulting in slowing of rapid turnover of epithelium.

11) When scales of psoriasis are removed tiny bleeding points (Auzpits sign) are observed. As Tikta \& Kashaya rasa has potent vranshodahan \& vranropan property Shatry (2003) \& Ghrita is well known for its healing action results in proper early healing of lesions of Psoriasis.

12) Vamana \& Virechana acts on microcellular level, eliminates the toxins (Vitiated doshas) from body \& helps in maintaining normal functioning of body. It strengthens the immune mechanism and helps in preventing relapse. 


\section{CONCLUSION}

- Both the groups show considerable efficacy which is highly significant clinically as well as statistically $(\mathrm{P}<0.001)$ however intergroup comparison shows that there is no major difference in efficacy of Ayurvedic trial drug \& control Allopathic drug. It suggests that Ayurvedic formulation is as much potent as Methotrexate in controlling the disease.

- The above data reveals that both drugs show highly significant results in reducing the PASI Score. Better resonse was seen in Kandu \& Daha in patients treated with Ayurvedic formulation.

- In liver function test significant increase in SGOT \& SGPT levels were observed in patients treated by Allopathic drug. Though the increased SGOT \&SGPT were in normal ranges it suggests that prolonged administration of drug may detoriate Liver functions. While in patients with Ayurvedic formulation no significant changes were observed. Thus, Ayurvedic formulation has distinct advantage in safety profile over Allopathic counterpart.

- Significant reduction in ESR which is supposed to be an inflammatory marker proves potent Anti-inflammatory action of Ayurvedic Trial drug.

- Relapse is major problem in treatment of Psoriasis. Ayurvedic trial drug shows 26\% relapse rate as compare to Methotrexate showing $46.33 \%$ relapse. It shows that Ayurvedic drug is more potent in preventing the relapse of disease than Allopathic counterpart.

Thus, it can be concluded that Ayurvedic trial Formulation has potent action in controlling disease as well as it is much better in preventing the recurrent relapse than standard allopathic regime. In safety profile Ayurvedic formulation has distinct advantage over allopathic counterpart.

\section{REFERENCES}

Archives of Dermatology (2001), quality of life survey, Journal of the American Academy of Dermatology (1999/41 pages 401 to 407).

Chunekar, K. C. (2009). Bhav Prakash Nighantu s.l. : Chaukhamba Bharati Acadamy. Vol. 1.

Chunekar, Krishnachanrda (2009) Bhavprakash Nighantu. s.l. : Chaukhamba Bharati Acadamy. Haritakyadi Varga/188-191.

Database of medicinal plants used in ayurvead (2000). s.l. : CCRAS,Gov. of India,. pp. 469-495. Vol. 1.

Database on medicinal plants used in Ayurveda (2000). s.l. : Cetral council for research in Ayurveda and Siddha, Gov. of India.,. Vols. 1-7.

Om Prakash Katare, Kaisar Raza, Bhupinder Singh, Sunil Dogra (2010). Novel Drug Delivert System in topical application of Psoriasis. 6, s.l. : Indian Journal of Dermatoloy,Venerology \& Leprology, Nov-Dec, Vol. 76, pp. 612-621. Retrieved from https://doi.org/10.4103/0378-6323.72451

P. P. Gupta, R.C. Srimal, Neeraj Verma and J.S. (1999) Tandon. Biological activity of rubia cordifolia and Isolation of an active principle.. 1, s.l. : Pharmaceutical Biology, Vol. 37, pp. 46-49. Retrieved from https://doi.org/10.1076/phbi.37.1.46.6322

Shatri, Satyanarayan (2003) Charak Samhita (Vidyotini Commentry). s.l. : Chaukhamba Bharati acadamy. Vimansthna 5/8. 
Shatry, Satyanarayan (2003). Charak Samhita (Vidyotini Commentry). s.l. : Chaukhamba Bharati Acadamy, pp. Sutra Sthana Adhyaya 26/42(5-6). Vol. 1

Shatry, Satyanarayana (2006). Charak Samhita Vidyotini Commentry. s.l. : Chaukhamba Bharati acadamy. p. Rasayan Adyaya 3 pada /42.

Tripathi, Bhramanand (2008). Sharanghdhara Samhita s.l. : Chukhamba surbharati Prakashana. Madhya khanda 2/136.

Tripathi, Dr. bramhanand (2008). Sharanghadhara Samhita s.l. : Chaukhamba Sur Bharati. Uttar Khanda 4/27-33.

Wai-Pui Tse, Chun-Tao Che, Ken Liu and Zhi-Xiu Lin (2006) evaluation of the anti proliferative property of selected psoriasis treating chinease medicine on culutured HaCa T cells.. 1, s.l. : Journal of Ethno Pharmacology, nov 3, Vol. 108, pp. 133-141. Retrieved from https://doi.org/10.1016/j.jep.2006.04.023

Z. X. Lin, B. W. Jiao, Z. Zuo, C. T. Che, C. F. Mok, M. Zhao (2010) Ethyl acetate fraction of root of Rubia cordifolia inhibits keratinocyte proliferationin vitro:Potential application for Psoriasis. 7, s.l. : Phytotherapy Research, , Vol. 24, pp. 1056-1064. Retrieved from https://doi.org/10.1002/ptr.3079 